The Review of Politics 83 (2021), 196-218.

(C) The Author(s), 2021. Published by Cambridge University Press on behalf of University of Notre Dame. This is an Open Access article, distributed under the terms of the Creative Commons Attribution licence (http://creativecommons.org/ licenses/by/4.0/), which permits unrestricted re-use, distribution, and reproduction in any medium, provided the original work is properly cited.

doi:10.1017/S0034670520001011

\title{
Francis Bacon on Imperial and Colonial Warfare
}

\section{Samuel Garrett Zeitlin}

\begin{abstract}
This article offers a textual and historical reconstruction of Francis Bacon's thought on imperial and colonial warfare. Bacon holds that conquest, acquisition of peoples and territory through force, followed by subjugation, confers a legal right and title. Imperial expansion is justified both by arguments concerning the interstate balance of power and by arguments related to internal order and stability. On Bacon's view, a successful state must be expansionist, for two key reasons: first, as long as its rivals are expansionist, a state must keep up and even try to outpace them, and, second, a surplus population will foment civil war unless this "surcharge of people" is farmed out to colonies. These arguments for imperial state expansion are held to justify both internal and external colonization and empire. Paradoxically, Bacon holds that the internally colonized may be treated with greater severity, as suppressed rebels, than the externally colonized, who are more fitly a subject of the ius gentium. Bacon holds that toleration offers both an imperial stratagem and a comparative justification for why English and British imperial expansion is more desirable than Spanish imperial expansion. The article concludes with reflections about how one might understand the place of imperial and colonial projects in Bacon's thought, contending that these projects are central to an understanding of Bacon's political aims and thought more broadly.
\end{abstract}

Francis Bacon (1561-1626) was deeply involved in various trans-Atlantic colonial projects, ${ }^{1}$ sitting as a member of Council for the Virginia Company of

Samuel Garrett Zeitlin is Hong Kong Link Early-Career Research Fellow and College Lecturer in Politics, Corpus Christi College, University of Cambridge, Trumpington Street, Cambridge CB2 1RH, United Kingdom of Great Britain and Northern Ireland (sgz21@cam.ac.uk).

The author thanks Ruth Abbey, Mark Bevir, Kelli Brown, Danielle Charette, Daragh Grant, Timothy Hampton, Kinch Hoekstra, Sarah Johnson, Victoria Kahn, Adam Lebovitz, Svetozar Minkov, Sankar Muthu, Jennifer Pitts, Richard Serjeantson, Shannon Stimson, Joanna Williamson, and three anonymous reviewers for helpful comments. The author is particularly grateful to Ruth Abbey and the editors of the Review of Politics for their patience and intellectual generosity.

\footnotetext{
${ }^{1}$ In a late nineteenth-century compilation of historical manuscripts on the English settlement of North America, Alexander Brown speculated that Bacon may have
} 
London from $1609^{2}$ and an incorporator of the Newfoundland Company in 1610 and of the Northwest Passage Company in 1612, and holding membership in the East India Company from 1618. ${ }^{3}$ Some scholars have been silent on the role of colonies in Bacon's political thought ${ }^{4}$ or persistently downplayed this aspect of his work in favor of a "classical republican" reading that eschews both empire ${ }^{5}$ and Bacon's colonial endeavors. ${ }^{6}$ Others have asserted

had a hand as solicitor general in drafting the Second Charter of the Virginia Company of 1609, in which Bacon is mentioned among those who "shall be our Council for the said Company of Adventurers and Planters in Virginia." Brown wrote, "This charter, it seems, was drafted by Sir Edwin Sandys, assisted possibly by Lord Bacon, both of whom were at that time members of his Majesty's Council for the company, and they were, about this time, assisting each other in drafting several instruments of writing, notably the 'remonstrance against the King's conduct toward the Parliament of 1604-1611.'" See Alexander Brown, ed., The Genesis of the United States; A Narrative of the Movement in England, 1605-1616, Which Resulted in the Plantation of North America by Englishmen, Disclosing the Contest between England and Spain for the Possession of the Soil Now Occupied by the United States of America (London: Heineman, 1890), 1:232, 207. Some details might give one pause about Brown's account, as in 1609 Bacon was not yet a lord. In his 1985 commentary on Bacon's Essayes, Michael Kiernan follows Brown's suggestion, writing that "the Second Charter for the Virginia Company (23 May 1609), which may have been prepared in part by Bacon in his capacity as Solicitor-General, established that the Governor be appointed by the Council in London." Michael Kiernan, "Commentary," in The Oxford Francis Bacon, ed. L. Jardine, G. Rees, R. W. Serjeantson, A. Stewart, and B. Vickers (Oxford: Oxford University Press, 1996-), 15:244. Hereafter OFB.

${ }^{2}$ Kiernan, "Commentary," in OFB, 15:239. See also Brown, Genesis of the United States, $1: 207,232$.

${ }^{3}$ Kiernan, “Commentary," in OFB, 15:239.

${ }^{4}$ Anthony Quinton, Francis Bacon (Oxford: Oxford University Press, 1980); Charles W. Lemmi, The Classic Deities in Bacon (Baltimore, MD: The Johns Hopkins Press, 1933); C. D. Broad, The Philosophy of Francis Bacon (Cambridge: Cambridge University Press, 1926). Cf. Michael Oakeshott, On Human Conduct (Oxford: Oxford University Press, 1975), 36, 287-91.

${ }^{5}$ Markku Peltonen, "Politics and Science: Francis Bacon and the True Greatness of States," Historical Journal 35, no. 2 (June 1992): 279-305; Markku Peltonen, “Bacon's Political Philosophy," in The Cambridge Companion to Francis Bacon, ed. Peltonen (Cambridge: Cambridge University Press, 1996), 283-310; Joanne Paul, Counsel and Command in Early Modern English Thought (Cambridge: Cambridge University Press, 2020), 118-21, 136-39. Cf. Quentin Skinner, Liberty before Liberalism (Cambridge: Cambridge University Press, 1998), 11-12.

${ }^{6}$ Wolfgang Krohn, Francis Bacon (Munich: Beck, 2006); S. G. Zeitlin, "'Commonwealth,' 'Nation,' and 'State' in the Political Thought of Francis Bacon," in The "Commonwealth" as Political Space in Late Renaissance England, ed. Luc Borot, Myriam-Isabelle Ducrocq, Raffaella Santi, and Samuel Garrett Zeitlin (Padua: CEDAM Editore, 2014), 3-26; Markku Peltonen, Classical Humanism and 
that colonial apologetics played no role in Bacon's thought. ${ }^{7}$ The present article, by contrast with these approaches, offers a textual and historical reconstruction of Bacon's thought on imperial and colonial warfare, examining a wider range of texts across Bacon's entire corpus, not least his governmental white papers and his concrete policy proposals for English colonies. Drawing on this wider source base, I argue that Bacon's political writings reflect and meditate on his colonial and imperial involvement.

The argument proceeds in seven sections. First, I argue that Bacon's colonial and imperial involvement, and his political thought regarding colonies and empire, were rooted in a view of imperial dominion based on a title of conquest. Second, one can see Bacon's view of the interrelation of colonization and warfare in his essay "Of Plantations" and its proposals for the Virginia Colony. Third, in Bacon's essay "Of Empire," one sees an argument for imperial expansion and warfare rooted in great power rivalry and the balance of power, particularly in relation to the Spanish Empire of the early seventeenth century. In the fourth and fifth sections, the article considers Bacon's commitments to colonial warfare in the light of his writings on suppressing internal rebellions and his writings on "greatness," both of which have implications for his writings on Irish colonization. Paradoxically, Bacon holds that the internally colonized may be treated with greater severity, as suppressed rebels, than the externally colonized, who are more fitly a subject of the ius gentium. Sixth, I offer an interpretation on Bacon's practical proposals for the colonization of Ireland to display the scope and extent of his colonial commitments, with particular attention, in a seventh and final section, to Bacon's advocacy of religious toleration as both an imperial stratagem and a comparative justification for why English and British imperial expansion is more desirable than Spanish imperial expansion. Throughout, the article emphasizes Bacon's concern with regime stability in his advocacy of empire and colonies. The article concludes with broader reflections about how one might understand the place of imperial and colonial projects in Bacon's thought.

Republicanism in English Political Thought, 1570-1640 (Cambridge: Cambridge University Press, 1995), 190-228.

${ }^{7}$ Sarah Irving, "'In a Pure Soil': Colonial Anxieties in the Work of Francis Bacon," History of European Ideas 32, no. 3 (2006): 261: "Francis Bacon was no ideological apologist for English colonisation." Bacon was not only without anxieties about colonization but also an active participant in and advocate of colonial projects. For the view that Bacon's Essayes offer "an endorsement of colonialism," see Svetozar Minkov, "Baconian Science and the Intelligibility of Human Experience: The Case of Love," Review of Politics 71, no. 3 (Summer 2009): 401. On Bacon's imperialism, see Michelle Tolman Clarke, “Uprooting Nebuchadnezzar's Tree: Francis Bacon's Criticism of Machiavellian Imperialism," Political Research Quarterly 61, no. 3 (Sept. 2008): 367-78. 


\section{The Title of the Sword}

Empire begins with acquisition through force, followed by subjugation, and Bacon's thought on the matter begins with the title of conquest. Conquest is enforced submission to sovereign authority. ${ }^{8}$ In laying out his view of kingship and obedience while arguing for the plaintiff in Calvin's Case in 1608, Bacon listed four original grounds which motivate and occasion human beings to submit themselves to obedience to a sovereign power: paternity, admiration of virtue, conduct in war, and conquest. ${ }^{9}$ Of these four modes, Bacon averred that he thought conduct in war "the most usual of all" and generative of a claim of obedience similar to paternity: "For as men owe their life and being to their parents in regard of generation, so they owe it also to saviours in the wars in regard of preservation." ${ }^{10}$ Conquest, Bacon argues in the immediately following sentences, generates a submission to sovereign authority similar to that generated by war conduct, "And this likewise is upon the same root, which is the saving or gift as it were of life and being. For the conqueror hath power of life and death over his captives; and therefore where he giveth them themselves, he may reserve upon such a gift what service and subjection he will." Both war conduct and conquest, in Bacon's argument, "are evident to be natural and more ancient than law."11 Hence conquest, in Bacon's view, is prior to law in time and generative of a submission to the sovereign power of a conqueror that grounds future legality.

In the dialogue An Advertisement touching an Holy War, Bacon's character Martius, "a Militar Man," gives voice to the view that the territorial acquisitions of Portugal under the reign of King Manuel I, not least all of Brazil, were famed "Conquests" which, in Martius's estimation, were spurred on by "Gold, and Siluer, and Temporall Profit, and Glory" rather than the pretended motive of "the Propagation, of the Christian faith."12 Speaking of "the famous Nauigations, and Conquests, of Emanuel, King of Portugall, whose Armes

${ }^{8}$ Bacon, The Case of the Post-Nati of Scotland, in The Works of Francis Bacon, ed. J. Spedding, R. L. Ellis, and D. D. Heath, 7 vols. (London, 1857-1859), 7:646. Hereafter SEH.

${ }^{9}$ Ibid., 645-46; Daniel R. Coquillette, Francis Bacon (Palo Alto, CA: Stanford University Press, 1992), 159. On the centrality of the broader theme of war in Bacon's thought, particularly in relation to Bacon's treatments of science, technology, and the mastery of nature, see Howard B. White, Peace Among the Willows: The Political Philosophy of Francis Bacon (The Hague: Martinus Nijhoff, 1968); Richard Kennington, On Modern Origins, ed. Pamela Kraus and Frank Hunt (Lanham, MD: Lexington Books, 2004), 1-77; Jerry Weinberger, Science, Faith, and Politics: Francis Bacon and the Utopian Roots of the Modern Age (Ithaca, NY: Cornell University Press, 1985); Robert K. Faulkner, Francis Bacon and the Project of Progress (Lanham, MD: Rowman \& Littlefield, 1993).

${ }^{10}$ SEH, 7:645.

${ }^{11}$ Ibid., 646.

${ }^{12}$ OFB, 8:191, lines 11-13; SEH, 7:21. 
beganne to circle Africke, and Asia," Martius emphasizes that "neither in this, was Religion the Principall, but Amplification, and Enlargement, of Riches, and Dominion." ${ }^{13}$ Martius seems to hold a similar view of the acquisitions of the Spanish "Castilians" who "opened the New World; And subdued, and planted Mexico, Peru, Chile, and other Parts of the West Indies." ${ }^{14}$ To the extent that to subdue is to compel another to submit by force, to claim, in Baconian terms, that a people or place is "subdued" by force is equivalent to claiming that that people or place has been conquered. Indeed, Bacon, arguing in Calvin's Case, understood conquest definitionally to be "inforced submission" to a sovereign authority. ${ }^{15}$ Martius thus boldly asserts that the title of Spanish and Portuguese holdings in the Americas and beyond is a title of conquest.

Bacon himself might seem to confirm this assessment when he argues hypothetically in Calvin's Case that "if king Henry VII. had accepted the offer of Christopher Columbus, whereby the Crown of England had obtained the Indies by conquest or occupation, all the Indies had been naturalized by the confession of the adverse part." Had Henry VII of England hired Columbus to explore on his behalf, the Americas would have accrued to him by title of "conquest or occupation," the very titles which Bacon's Martius attributes to Portugal and Spain. ${ }^{16}$

On the note of conquest, Bacon opens his Historie of the Raigne of King Henry the Seventh (1622) by stressing Henry's title to rule from conquest, having vanquished the forces of Richard III at Bosworth Field, ${ }_{1}^{17}$ noting that upon the victory, Henry was "in a kind of Militar Election, or Recognition, saluted King." ${ }^{18}$ In this history, dedicated to the heir apparent to the throne, Charles, then Prince of Wales, Bacon stresses that this "Militar Election" amounted to a title to the English crown by "the Title of the Sword or Conquest,"19 a title which was accompanied by two hereditary titles: a Yorkist title to rule by marriage to the Lady Elizabeth of York, the eldest daughter of Edward IV; ${ }^{20}$ and a Lancastrian title in his own person as heir to Kings Henry VI, V, and IV. Both of the hereditary titles, Bacon emphasized, had their pitfalls: although acknowledging the title derived from the House of York to be "fairest," ${ }^{21}$ Bacon observed that if Henry chose to rule through the Yorkist title "he could be but a King at Curtesie, and haue rather a Matrimoniall

${ }^{13}$ OFB, 8:191, lines 15-21; SEH, 7:21.

${ }^{14}$ OFB, 8:190, lines 29-30; 191, line 1; SEH, 7:20.

${ }^{15}$ SEH, 7:646.

${ }^{16}$ Ibid., 659.

${ }^{17}$ OFB, 8:4, lines 6-9.

${ }^{18}$ Ibid., lines 15-16.

${ }^{19} \mathrm{OFB}, 8: 5$, line 31. On conquest and titles to rule in Bacon's Historie of the Raigne, see Jerry Weinberger, "The Politics of Bacon's History of Henry the Seventh," Review of Politics 52, no. 4 (Fall 1990): 561-62.

${ }^{20}$ Kiernan, "Commentary," in OFB, 8:296.

${ }^{21}$ OFB, 8:5, line 33 . 
then a Regall power" as he would hold title only via his wife and would be imperilled upon her surcease with rival claims to the throne. ${ }^{22}$

While remarking that Henry was crowned upon his victory at Bosworth Field "as if there were his chiefe Title," ${ }^{23}$ Bacon stresses that publicly avowing to rule by conquest carries its own political and historical heft, not only scaring away potential friends and potentially encouraging regimental foes but also recalling historical memories of the Norman Conquest, when even "WILLIAM himselfe, commonly called the Conqueror, howsoeuer he vsed and exercised the power of a Conqueror to reward his Normans, yet he forbare to vse that Claime in the beginning, but mixed it with a Titularie pretence grounded vpon the Will and designation of EDWARD the Confessor." 24 Public reliance on the title of conquest, even if, in Bacon's assessment, such a title is juridically sound, is politically precarious: it frightens both allies and adversaries with the prospect of suspending the orderly rule of law, bearing the imprint of "like points of absolute power." ${ }^{25}$ In the case of Henry VII, Bacon distinguishes claiming as a conqueror from ruling as a conqueror-and commends Henry's "greatnesse" of mind in foregrounding his claim to rule as the heir of the Lancastrian line while keeping his claim of conquest and title of "Battaile" to "beate downe open murmer and dispute." ${ }^{26}$ In short, Bacon presents his Henry as following William the Conqueror's example: forbearing "to vse that Claime" but nonetheless exercising the power of a Conqueror.

Bacon is quite emphatic that conquest forms one of Henry VII's "three seuerall Titles to the Imperiall Crowne." ${ }^{27}$ His prudent counsel with regard to Henry's title by conquest is that it is important to rule by right of conquest in such a manner as to quell dissent and the propensity to revolt without the odious aftertaste of claiming as a conqueror. To this end, Bacon presents his Henry as eager to multiply his formal and legal titles by procuring swift papal and parliamentary confirmation of his right to rule, so that by March of 1486 he had received both statutory confirmation and a Papal Bull affirming him as king of England "with mention neuerthelesse (by waie of recitall)

\footnotetext{
${ }^{22}$ Ibid., 5-6.

${ }^{23}$ Ibid., 6, lines 24-25.
}

${ }^{24}$ Ibid., lines 30-34. On English mistrust of the title of conquest in the period of European imperial expansion, Anthony Pagden writes, "there existed a longstanding distrust of conquest . . . that originated in the Norman occupation after 1066 and resulted in the 'continuity theory' of constitutional law in which the legal and political institutions of the conquered are deemd to survive a conquest." Anthony Pagden, The Burdens of Empire, 1539 to the Present (Cambridge: Cambridge University Press, 2015), 123-24. See also J. G. A. Pocock, The Ancient Constitution and the Feudal Law (Cambridge: Cambridge University Press, 1987), 42-45, 53-55.

${ }^{25}$ OFB, 8:6, line 29.

${ }^{26}$ Ibid., 7 , lines 8-9.

${ }^{27}$ Ibid., 5, lines 26-27. 
of his other titles both of discent and Conquest." ${ }^{28}$ Conquest is again presented as temporally prior to confirmation by statute or religious authority and is affirmed by a "wise king" in the very act of augmenting the titles to dissimulate it.

Bacon's reflections on the title of conquest in his Historie of the Raigne might be extended to his treatment of colonial titles to rule. While he urges his colonial administrators to act as conquerors, forcing others to submit to the Crown's authority, he does not foreground the claim of legal title to conquest. As a counselor for empire and colonial plantations, Bacon urges his addressees to govern as conquerors while keeping an adept silence about their title by conquest. $^{29}$

In view of Bacon's thought that conquest is a natural title of obedience to a sovereign power, let us look more closely at how Bacon relates his thought on war and empire to his thought on colonies or plantations.

\section{Martial Law in “Of Plantations" (1625)}

Addressed to the Duke of Buckingham, then the royal favorite and leading advocate of war with Spain, Bacon's "Of Plantations," Essay 33 in the 1625 edition of his Essayes, was translated into Latin as "De Plantationibus Populorum, et Coloniis" (On the plantations of peoples, and colonies) in the 1638 edition of Bacon's Opera Civilia et Moralia. ${ }^{30}$ Bacon's vocabulary of "plantations" was thought by his literary agents and translators, whose number, according to John Aubrey, included the philosopher Thomas Hobbes, ${ }^{31}$ to be close enough to that of "colonies" that they translated the terms as at least partial equivalents.

In "Of Plantations," Bacon ties his notion of a "plantation" or planting colony to war in at least three senses. The first connection between plantations and war is Bacon's claim that plantations should be governed by those with a commission or authority to exercise martial law, keeping silent about the fact that to rule by martial law is to rule as a conqueror. The second connection Bacon draws are the stratagems he proposes for colonial rule. Finally, Bacon stresses a connection between plantations and war in the relation of colonial settlement to the native populations, which serves, for Bacon, as a

${ }^{28}$ Ibid., 11, lines 26-27.

${ }^{29}$ As Anthony Pagden writes, "Although very few of the English settlements in America were in fact 'conquered' in any meaningful sense, conquest nevertheless remained the basis of the English crown's claim to its American colonies until independence." Pagden, Burdens of Empire, 124.

${ }^{30}$ Bacon, Opera Moralia et Civilia, ed. William Rawley (London: Richard Whitaker, 1638), 217.

${ }^{31}$ John Aubrey, "Thomas Hobbes," in Brief Lives, chiefly of Contemporaries, set down by John Aubrey, between the Years 1669 \& 1696, ed. Andrew Clark (Oxford: Clarendon, 1898), 1:331. 
ground of legitimation for English and British colonies over and against Spanish imperial power in particular.

With regard to the first connection, Bacon claims that such plantations should be governed by those with a commission or the authority to exercise martial law: "let them have Commission, to exercise Martiall Lawes," 32 to the end that the plantation may run smoothly. Martial law, in Bacon's view, was fitly invoked for the suppression of rebellion as well as the administration of colonial plantations. Bacon opens his 1601 Declaration touching the Treasons of the Late Earl of Essex and His Complices with the concession that while Essex and his associates received "an honourable and ordinary trial," Essex's case would not only have "borne" but "required" the "severity of martial law" to bring the matter swiftly to justice. ${ }^{33}$ In Historie of the Raigne of King Henry the Seventh, Bacon further commends his Henry following his victory at the Battle of Stoke Field in 1487 for his use of prerogative justice "partly by Martiall Lawe and partly by Commission" to punish those who aided the Earl of Lincoln and his Yorkist rebellion. ${ }^{34}$

In Bacon's preferred colonial administration, the commission to exercise martial law is to be held in the hands of a well-counseled governor, who is to rule the plantation monarchically or at least quasi-monarchically: "For the Government, let it be in the Hands of one, assisted with some Counsell." This counsel is not to be too numerous and is to be composed of "Noblemen, and Gentlemen." 35 Juridically, as Ken MacMillan has argued, colonies were a space of regal prerogative in which the Roman civil law of equity rather than the common law obtained. ${ }^{36}$ Bacon's avid endorsement of martial law, placing colonies on a war footing, might be seen not only as advocacy of this use of prerogative but as a stark amplification of it.

The second way Bacon ties his "plantations" to war is in the stratagems he proposes for their management. Food is to be rationed on the model of a state of siege: "The Victuall in Plantations, ought to be expended, almost as in a Besieged Towne." 37 Third, moreover, in "Of Plantations" war is pertinent to how settlers or colonists in a "plantation" relate to native populations. Planters and settlers are to conduct themselves toward native populations "with sufficient Guard." Bacon counsels against waging offensive war on behalf of local populations to win their favor, but concedes that coming to the aid of a native people when that people is attacked may be permissible

${ }^{32}$ OFB, 15:107.

${ }^{33}$ Bacon, A Declaration touching the Treasons of the late Earl of Essex and His Complices, in The Letters and the Life of Francis Bacon including All His Occasional Works, ed. J. Spedding, 7 vols. (London, 1861-1874), 2:247. Herafter LL.

${ }^{34} O F B, 8: 30$, lines 7-8, with Kiernan, “Commentary," in OFB, 8:331-34.

${ }^{35}$ OFB, 15:107.

${ }^{36}$ Ken MacMillan, Sovereignty and Possession in the English New World: The Legal Foundations of Empire, 1576-1640 (Cambridge: Cambridge University Press, 2006), 7.

${ }^{37}$ OFB, 15:107. 
for the purpose of earning their esteem: "doe not winne their favour, by helping them to invade their Enemies, but for their Defence it is not amisse." ${ }^{\prime 38}$ Bacon's counsel approving defensive but disapproving invasive wars in "Of Plantations" therefore seems to parallel his rhetorical and conceptual distinction between invasive and defensive war in his 1624 white paper on war with Spain. ${ }^{39}$

In a similar vein, Bacon explicitly juxtaposes the English practice of colonization with his image of the Spanish practice of empire in the Americas. ${ }^{40}$ In his 1622/3 dialogue, Advertisement touching an Holy War, his character Zebedaeus, endowed with the persona "of a ... Zelant" ${ }^{41}$ and instilled with a "fervid" (fervidus) disposition, makes several strong assertions advancing Spain's claims to overseas dominion on the grounds of "the Law of Nature." 42 "The Law of Nature," Bacon's Zebedaeus asserts, proscribes the custom of eating human flesh; thus, this "Law of Nature" grants just cause to the Spanish imperial power to expel and reduce those who have adopted this custom. ${ }^{43}$

Drawing an ideological contrast to this picture, Bacon's proposed mode for "plantations" and settler populations seeking amity with native populations is not mediation, but defensive war on behalf of the native population with which a colonial and imperial power seeks alliance. Alliances made by colonies and "plantations," for Bacon, writing on the Virginia Colony in "Of Plantations," are sought by means of war. In his parliamentary speech on behalf of the 1597 Subsidy Bill, Bacon would critique Spanish colonial rule for "the great and barbarous cruelties which they have committed upon the poor Indians" - where, in his presentation, the Spanish colonial power, and not the Native Americans, is described as "barbarous." ${ }^{44}$ Across his political and literary career, from his parliamentary speeches in the 1590s to his writings after his fall from power, Bacon deployed his juxtaposition of his favored mode of English engagement with native populations in contrast to Spanish colonial administration as an ideological warrant for the superiority of English and British claims to empire over and against their Spanish opponents.

These facets of Bacon's presentation of his favored modes of colonial administration in relation to war and empire occasion a further look at

${ }^{38}$ Ibid., 108.

${ }^{39}$ Bacon, Considerations touching a War with Spain, in LL, 7:469-505.

${ }^{40}$ Bacon, Opera Moralia et Civilia, 335: "Zebedaeus Romano-Catholicus, fervidus, \& Zelotes." See also SEH, 7:17n2; OFB, 8:187; Kiernan, "Commentary," in OFB, 8:496. Michelle Tolman Clarke picks up on this rhetorical strategy, but places it among English and French imperial rhetorical strategies in the period after Bacon wrote. See Tolman Clarke, "Uprooting Nebuchadnezzar's Tree," 377.

${ }^{41}$ OFB, 8:187; Bacon, Opera Moralia et Civilia, 335.

${ }^{42}$ OFB, 8:205; Bacon, Opera Moralia et Civilia, 348.

${ }^{43}$ Bacon, Opera Moralia et Civilia, 348; OFB, 8:205 and SEH, 7:34. On Bacon's views on just warfare, see Samuel Garrett Zeitlin, "Francis Bacon on Just Warfare," in The Political Science Reviewer 45:1 (2021).

${ }^{44} L L, 2: 88$. 
Baconian colonies in relation to profit and war. Indeed, Bacon has a series of concerns which he wishes to emphasize in "Of Plantations." First and foremost, he is concerned for the stability and longevity ${ }^{45}$ of plantations and his subsequent concerns are aimed at securing this. Subordinated to the concern for stability are concerns for the population, for hygiene, and for the long-term profitability of the plantations or colonies.

The theme of profit had been articulated by Bacon at least as early as 1609 in De Sapientia Veterum (On the wisdom of the ancients), his allegorical mythography in which fables are turned to the end of conceptual elucidation. In the fable of Perseus, Bacon advises that "profit" (fructus) is a key consideration in the expansion of empire which differentiates empire building from expanding a private land-holding, writing that "Nor, indeed, is the rationality of augmenting a patrimony the same as that of expanding an empire. For in private possessions, one ought to look to the proximity of the loot; but in propagating empire, occasion, both the ease of waging war and the profit of waging war, ought to be looked to in place of the proximity." ${ }^{46}$ While some writers have downplayed the role and prominence of profit in the writings of the natural philosophers on the imperial theme, ${ }^{47}$ the notion was important in Bacon's political writings and he emphasized it with greater force and frequency in "Of Plantations" to the extent that it overshadows both explicit biblical quotation and appeals to virtue in that essay. In setting out to establish a plantation or colony, "you must make account, to leese almost Twenty yeeres Profit, and expect your Recompence, in the end." ${ }^{48}$ It was a miscalculation of profit structure, not a misunderstanding of the Bible or of virtue, which had led past plantations in the Americas to fail: Bacon writes that "the Principall Thing, that hath beene the Destruction of most Plantations, hath beene the Base, and Hastie drawing of Profit, in the first Yeeres." ${ }^{\prime 9}$ Profit is not, in Bacon's estimation, a matter to be neglected in the early stages of a plantation, but it must be pursued in a way that is compatible with the establishment of a plantation that may be of long duration. ${ }^{50}$

In this argument, Bacon appears to reiterate a critique of the management of the Virginia Company made by John Smith in a 1608 letter to the treasurer of the company, in which he lamented that "in overtoyling our weake and

${ }^{45}$ Compare Peltonen, Classical Humanism and Republicanism, 198.

${ }^{46}$ Bacon, De Sapientia Veterum, in SEH, 6:642 (my translation). Cf. SEH, 6:715.

47 "There is little space in this debate for a discussion of the sixteenth- and seventeenth-century intellectual origins of the British Empire, in which ideas of profit and capital were less important than those of virtue or Old Testament theology, for example." Sarah Irving, Natural Science and the Origins of the British Empire (London: Pickering \& Chatto, 2008), 5. See further Andrew Fitzmaurice, Humanism and America: An Intellectual History of English Colonisation, 1500-1625 (Cambridge: Cambridge University Press, 2003), 3.

${ }^{48}$ Bacon, "Of Plantations," in OFB, 15:106, lines 10-12.

${ }^{49}$ Ibid., lines 12-14. Cf. Weinberger, Science, Faith, and Politics, 129.

${ }^{50} \mathrm{OFB}, 15: 106$, lines 14-16. 
unskilfull bodies, to satisfie this desire of present profit, we can scarce ever recover ourselves from one supply to another." ${ }^{51}$ Bacon, like Captain Smith, was criticizing not the pursuit of profit generally, but the overhasty pursuit of "present profit," checking the long-term stability and profitability of the Virginia plantation. Not least, in his choice of crops for growing in a colony, Bacon commends those which "cannot but yeeld great Profit." ${ }^{2}$ With regard to colonies or plantations, a discourse of and concern with "Profit" calls into question the interpretations of those writers who downplay Bacon's advocacy for colonies and empire as well as interpreters who claim that early modern humanists, like Bacon, approached colonization with "outright hostility." 53

"Of Plantations" ends with a strong admonition against abandoning a colony once planted or begun: such abandonment amounts to "sin," or particularly loathsome betrayal. "It is the sinfullest Thing in the world," Bacon claims, "to forsake or destitute a Plantation, once in Forwardnesse." Plantations seem thus to give rise to obligations on the part of the imperial or "planting" power, and are thus not wholly reducible to the advantages which they provide.

Further pursuing a reconstruction of Bacon's thought on colonies and empire, a consideration of Bacon's essay "Of Empire" may shed light on his caution against rendering destitute a plantation once established.

\section{Bacon's “Of Empire" (1612/1625)}

In "Of Empire," the term "empire" itself is undefined. Indeed, in the 1612 edition of the Essaies of Sir Francis Bacon Knight, the Kings Solliciter Generall, ${ }^{55}$ beyond the title of the essay, the word "empire" is entirely absent from "Of Empire." ${ }^{56}$ Revising the essay for the 1625 edition, Bacon altered his claim that "A true temper of gouernment is a rare thing" 57 to claim of "the true Temper of Empire: It is a Thing rare, and hard to keep," thereby replacing "gouernment" with "empire" and introducing the latter into the body of the text, while at the same time retaining a cross-referent to "gouernment" later in the same paragraph and thereby implying that

51 "Smith to the Treasurer of Virginia" (1608), in John Smith, History of Virginia (London, 1624), 70-72, reprinted in Brown, Genesis of the United States, 1:203-4.

${ }^{52}$ Bacon, "Of Plantations," in OFB, 15:107, lines 61-62: "So Drugs, and, Sweet Woods, where they are, cannot but yeeld great Profit."

${ }^{53}$ Fitzmaurice, Humanism and America, 3. See also Irving, Natural Science, 5; Peltonen, Classical Humanism and Republicanism.

${ }^{54}$ Bacon, "Of Plantations," in OFB, 15:108.

${ }^{55}$ SEH, 6:537-91.

${ }^{56}$ Bacon, "Of Empire," in SEH, 6:552-53.

${ }^{57}$ Ibid., 553.

${ }^{58}$ Bacon, "Of Empire," in OFB, 15:59, lines 33-34. 
empire and a certain mode of government were semantically interchangeable. $^{59}$

"Of Empire" is concerned, in the first instance, with "the Case of Kings," treating the modes of monarchic rule and the relations which a successful monarch must keep. ${ }^{60}$ Bacon counsels monarchs to look first to their neighbors, from whom "arise Dangers, if Care and Circumspection be not used." 61 Bacon emphasizes that their greatness and expansion must be checked, since "for their Neighbours; There can no generall Rule be given, (The Occasions are so variable, save one; which ever holdeth; which is, That Princes doe keepe due Centinell, that none of their Neighbours doe overgrow so, (by Encrease of Territory, by Embracing of Trade, by Approaches, or the like) as they become more able to annoy them, then they were." 62 This is Bacon's only rule regarding foreign policy articulated in "Of Empire." In stressing keeping pace with the growth of neighboring powers, he emphasizes a general rule of seemingly perpetual temporal ambit ("which ever holdeth") and of broad scope: monarchs must keenly attend that their neighbors' relative power position in territory, trade, navigation, or martial access does not grow in any respect: neighbors must not be allowed to expand relative to one's power so that they be "more able to annoy them, then they were." 63 The easiest way to satisfy Bacon's general rule is for one's own power to expand in territory, trade, and "Approaches" faster than all other neighboring powers - this would satisfy Bacon's sole rule for foreign affairs articulated in "Of Empire": only when no neighboring power's growth exceeds one's own is a monarch's state secure.

Bacon's 1624 Considerations touching a War with Spain would apply precisely this perpetual maxim to the most salient contemporary case, that of Spain, with Bacon warning the heir apparent, Prince Charles, that "nothing is more manifest, than that this nation of Spain runs a race (still) of empire when all other states of Christendom stand in effect at a stay." ${ }^{\prime 64}$ In this matter no other state, Britain least of all, can afford to be an onlooker: Spain's augmentation of territory and, not least, titles of conquest should ring a bell of warning, Spain's "so many new conquests and purchases" should sound "so many strokes of the larum bell of fear and awaking to other nations." 65

${ }^{59}$ Ibid., lines 33-34 with line 39; SEH, 6:553.

${ }^{60} \mathrm{OFB}, 15: 58$, lines 4-5. Daniel Coquillette notes that in questions of conflicting obligations in politics, "Bacon chose, as he always did, the royal side." Coquillette, Francis Bacon, 185n143.

${ }^{61}$ OFB, 15:60, lines 61-62.

${ }^{62}$ Ibid., lines 63-69.

${ }^{63}$ Ibid.

${ }^{64}$ Bacon, Considerations touching a War with Spain, in $L L, 7: 479$. Cf. OFB, 15:60, lines 62-70.

${ }^{65} L L, 7: 479$. 
The Baconian maxim from "Of Empire," combined with its politic application in his Considerations, sheds light on why, in Bacon's estimation, abandoning a colony is superlatively sinful: if a neighbor power, say, Spain, is growing in colonies, then to maintain a state secure, England or Britain must grow in colonies at an equivalent rate. Otherwise, relative power diminishes and one risks the loss of one's state.

\section{Plantations and the Bounds of Empire}

If colonies expand the bounds of empire, one might ask whether every colony or plantation would count as an expansion of empire for Bacon. It would seem that colonies may serve both for the expansion of empire (the case of Virginia) but also for the restitution of empire or the reclaiming of territories and peoples which, in his view, seem to have fallen away from obedience to the Crown (the latter case being that of Ireland). Similarly, one might ask whether every expansion of the bounds of empire, for Bacon, must take the form of a colony. It would seem, in this case, that it would not, as, for Bacon, empire may be extended by the expansion of imperium at sea. Naval and maritime empire, for Bacon, was a necessary constituent of greatness as well as a central component of expanding one's imperium into the New World. ${ }^{66}$

For Bacon, both empire and colonies are juridically rooted in titles of conquest. Indeed, in the case of Ireland, Bacon emphasizes in Calvin's Case that the Irish are naturalized by conquest ${ }^{67}$ and he collapses the distinction between naturalization by conquest and naturalization by descent in a manner which makes the juridical rights of a sovereign by descent equivalent to those of a sovereign by conquest. ${ }^{68}$ In "Of Empire," Bacon instructs his addressee in the 1625 Essayes, Lord Admiral Buckingham, that conquest is a rightful and happy act of kings: Bacon writes of "Kings, that have beene fortunate Conquerours in their first yeares," who descend into "Melancholy" when the rate of their conquests slows. ${ }^{69}$

While some scholars have claimed that Bacon favors a federative model of colonial and imperial government, ${ }^{70}$ plantations and colonies are nonfederative and to be governed monarchically, as we have seen. To the extent that Ireland does serve as a model for plantation in the New World, ${ }^{71}$ coupled

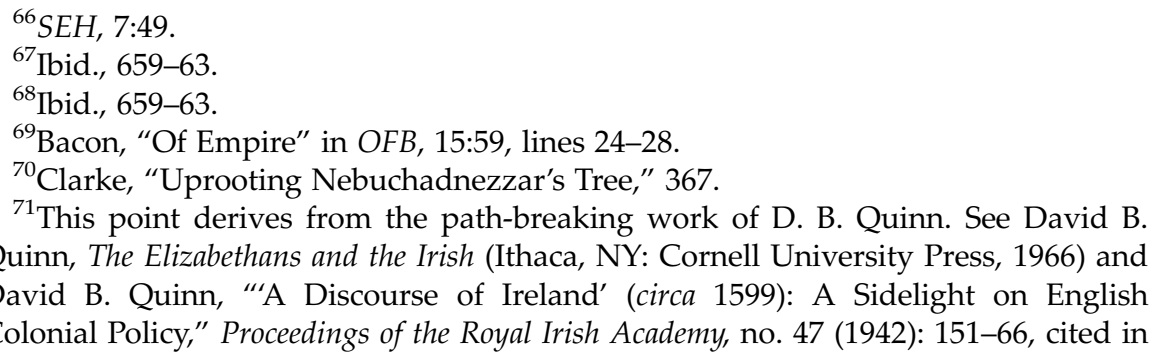


with Bacon's proposal that Irish noblemen should be welcome at the court of King James, Bacon would seem to favor the expansion (over time) of all of the rights of English subjects to Irish subjects as well, following Bacon's express preference in Calvin's Case. ${ }^{72}$ If this is the model for Bacon's view of colonial government, he would seem to favor an expansive empire in which subjects in plantations may attend the English court and may ultimately share in English rights and representation. ${ }^{73}$ Residents of English colonial plantations would thus be equal subjects in an imperial monarchy bounded only by the relative expansion of its opponent states.

\section{Of the True Greatness of the Kingdom of Britain and the Question of Internal Order}

It has been well observed that certain important passages from Bacon's incomplete "Of the True Greatness of the Kingdom of Britain" find their way into his later essays. ${ }^{74}$ Less often noted is the bearing of this work on questions of internal order and the suppression of "inward rebellion." Attentive to the problem of internal order in this early fragment, Bacon wrote that "There be two manners of securing large territories: the one by the natural arms of every province; and the other by the protecting arms of the principal estate, in which case commonly the provincials are held disarmed. So are there two dangers incident to every estate; foreign invasion, and inward rebellion." 75 Looking to the question of compact territory, which Bacon prefers to dispersed territory in the absence of a maritime imperium, he writes that "if the parts of an estate be disjoined and remote, and so be interrupted with the provinces of another sovereignty, they cannot possibly have ready succours in case of invasion, nor ready suppression in case of rebellion."76

Looking further to the question of the best mode by which a state may expand, Bacon writes that "it is necessary in a state that shall grow and inlarge, that there be that composition which the poet speaketh of, Multis utile bellum; an ill condition of a state (no question) if it be meant of a civil war, as it was spoken; but a condition proper to a state that shall increase, if it be taken of a foreign war." ${ }^{77}$ This last passage, with its reference to

R. W. Serjeantson, "Francis Bacon, Colonization, and the Limits of Atlanticism" (lecture, University of California, Berkeley, March 2014).

${ }^{72}$ Bacon, Case of the Post-Nati, in SEH, 7:659.

${ }^{73}$ Ibid., 649.

${ }^{74}$ Peltonen, "Politics and Science," 282-84.

${ }^{75}$ Bacon, "Of the True Greatness of the Kingdom of Britain," in SEH, 7:49.

${ }^{76}$ Ibid., 51.

${ }^{77}$ Ibid., 59; Lucan, De bello civile 1.182, in Lucan, The Civil War, ed. J. D. Duff (Cambridge, MA: Harvard University Press, 1928), 16-17. 
Lucan's Bellum civile, is borrowed not for Bacon's later essay "Of the Greatness of Kingdomes" but rather for his essay "Of Seditions and Troubles," where it is present in both the manuscript for the 1612 edition of the Essaies (from the print version of which it was withheld) and in the 1625 edition of the Essayes or Counsels, Civill and Morall. Where Bacon repeats the earlier passage, he writes that "Lucan noteth well the state of the tymes before the civill warre: Hinc usura vorax, rapidumque in tempore fonus, / Hinc concussa fides, et multis utile bellum. This same Multis utile bellum is an assured and infallible signe of a State disposed to troubles and seditions." ${ }^{78}$ In the later essay, Bacon omits his earlier conclusion from his "True Greatness of Britain": the composition of the population which is good for external expansion (namely, that a part of it be desperate and impoverished $)^{79}$ also makes for conditions ripe for civil war. ${ }^{80}$ In sum, the conditions that equip a state for imperial and colonial conquest (above all, surcharge of a warlike and impoverished population) also make for the conditions ripe for internal civil war, particularly if a policy of imperial and colonial expansion is not pursued.

From this repetition of parts of Bacon's fragment "Of the True Greatness of the Kingdom of Britain" incorporated into the argument of the essay "Of Seditions and Troubles," we see that Bacon's concern with greatness, which is integrally related to his preference for colonies, is importantly concerned with aspects of both internal order (civic peace) and external order (expanding the bounds of empire). Colonies solve a problem of internal order because they allow for the redistribution of population, ${ }^{81}$ which Bacon regarded as excessive within England, at the same time that they facilitate the equalization of land tenures, a condition he regarded as crucial to the formation of a virtuous and martial population. It is easier to equalize land holdings in the newly founded Virginia Colony than it is in long-since-founded Surrey or Kent.

Bacon lays out three conditions in "Of the True Greatness of the Kingdom of Britain" in which wealth and riches can be a force multiplier, but all of which are based on a situation in which a population is skilled in warfare and prepared to exercise martial valor: ${ }^{82}$

\footnotetext{
${ }^{78}$ SEH, 6:590; Bacon, "Of Seditions and Troubles," in OFB, 15:45, lines 83-88; Michael Kiernan, "Commentary," in OFB, 15:203. Cf. Lucan, De bello civile 1.181-82, in Civil War, 16-17. For an account of the political reception of Lucan in England from the second half of the reign of Elizabeth I to the English Civil War see Edward Paleit, War, Liberty, and Caesar: Responses to Lucan's "Bellum Ciuile," ca. 1580-1650 (Oxford: Oxford University Press, 2013), which does not mention Bacon's appropriation of this passage.

${ }^{79}$ Bacon, "Of the True Greatness of the Kingdom of Britain," in SEH, 7:59.

${ }^{80}$ On this theme, White notes that "Bacon feared the common people, because he feared civil war." White, Peace among the Willows, 39. On Bacon on civil war, see Samuel G. Zeitlin, “The Heat of a Feaver': Francis Bacon on civil war, sedition, and rebellion," in History of European Ideas (forthcoming).

${ }^{81}$ Bacon, Case of the Post-Nati, in SEH, 7:661.

${ }^{82}$ Compare Peltonen, Classical Humanism, 199-200.
} 
Treasure and moneys do then add true greatness and strength to a state, when they are accompanied with these three conditions:

First, (the same condition which hath been annexed to largeness of territory,) that is, that they be joined with martial prowess and valour.

Secondly, That treasure doth then advance greatness, when it is rather in mediocrity than in great abundance. And again better when some part of the state is poor, than when all parts of it are rich.

And lastly, That treasure in a state is more or less serviceable, as the hands are in which the wealth chiefly resteth. ${ }^{83}$

These conditions stand in complicated relation to Bacon's discussion of the distribution of wealth in "Of Seditions and Troubles." ${ }^{84}$ Perhaps an uneven distribution of wealth is superior for fostering external conquest, but may elicit the conditions which foment rebellion. Here, again, Bacon implies that the situation most ripe for a state's imperial expansion (overpopulation and resource inequality) is also that most apt to lead to internal conflict if that expansion is not pursued.

\section{The Irish Plantation}

In light of the relation which Bacon posits between external expansion and the prevention of rebellion and civil war, it is worth taking a closer look at his practical proposals for the colonization of Ireland in relation to the colonization of the Americas.

In keeping with his interest in Ireland, Bacon had assiduous interest in advising the Earl of Essex before his ill-fated 1599 expedition to defeat Tyrone's Rebellion, with the aim of furthering Essex's success by a letter of counsel. Bacon frames the "reduction of that whole kingdom" of Ireland as a matter of enacting "God's providence," comparing the reduction he wishes for in 1599 to that achieved in the 1580s following the suppression of the earlier Desmond Rebellion. ${ }^{85}$ Importantly for Bacon, such a reduction is only the beginning of what must be done by Essex in Ireland - "the end may be pacique imponere morem, to replant and refound the policy of that nation" ${ }^{86}$-the imposition of peace and morality, with a replanting of Ireland to England's wishes. To impose peace and morality when putting down rebellion amounts, in Bacon's legal definition, to forcing the Earl of Tyrone and his followers to submit to the English Crown. Since enforced

\footnotetext{
${ }^{83}$ Bacon, "Of the True Greatness of the Kingdom of Britain," in SEH, 7:58.

${ }^{84}$ Bacon, "Of Seditions and Troubles," in OFB, vol. 15.

${ }^{85}$ Bacon, "A Letter of Advice to My Lord of Essex," in $L L, 2: 130$.

${ }^{86}$ Ibid., 131-32. On Bacon's view of what peace entails, see Samuel Garrett Zeitlin, "Francis Bacon on Peace and the 1604 Treaty of London," History of Political Thought 41:3 (Autumn 2020): 487-504. On the contrasting Hobbesian notion of peace, see Samuel Garrett Zeitlin, "Interpretation and Critique: Jacob Taubes, Julien Freund, and the Interpretation of Hobbes," Telos 181 (Winter 2017): 17-20.
} 
submission is Bacon's juridical definition of conquest itself, ${ }^{87}$ Essex's brief, from Bacon's perspective, is that of the reconquest of County Tyrone. ${ }^{88}$ In his advice to Essex, Bacon is keen to compare the Irish to Native Americans in terms most unfavorable to the former, urging Essex to engage in "a recovery of them not only to obedience, but to humanity and policy, from more than Indian barbarism. ${ }^{\prime 89}$ Essex's expedition and the suppression of Tyrone's Rebellion is to be a mission of pacification with civilizing intent-one which aims at the imposition of both peace and manners (pacique imponere morem). ${ }^{90}$

In his discussion of English plantations or colonies in Ireland, particularly in the north of Ireland, Bacon links the issue of Anglo-Scottish Union to the question of the colonization of Ulster, and of County Tyrone in particular. In a letter to King James, dated to January $1608 / 9,{ }^{91}$ speaking of plans for a plantation in the northern counties of Ireland, Bacon reckons "this action as a second brother to the Union. For I assure myself that England, Scotland, and Ireland well united is such a trefoil as no prince except yourself (who are the worthiest) weareth in his crown." ${ }^{92}$

Bacon's 1608/9 Considerations give support to the issue of transportation of population, ${ }^{93}$ which is primarily the transportation of English and Scottish gentry into Ireland. Bacon envisages that "the people transported will consist of gentlemen and their servants, and of labourers and hinds, and not of yeomen of any wealth." ${ }^{94}$ He wishes for yeomen to remain rather in England and Scotland and for craftspersons to be transported for American colonization. ${ }^{95}$ It is above all in the question of the "quality" of persons ${ }^{96}$ who are to be planted in Ulster that Bacon differentiates the "plantation" of Ulster from the "plantation" in Virginia. However, Bacon's differentiation of the type of persons who are most fit to colonize America and Ireland, respectively, belies an underlying similarity of Bacon's approach to plantations generally: he regards Ireland, like America, as a place in which "your Majesty shall build in solo puro et in area pura"97 - a place of "pure" soil and locale, which is to say, in effect, an empty place. Both Ulster and America are places to build in solo puro and may thus bear resemblance to

${ }^{87}$ SEH, 7:646.

${ }^{88}$ Bacon, "Letter of Advice," in LL, 2:131-32.

${ }^{89}$ Ibid., 130.

${ }^{90}$ Ibid., 131-32. See also Bacon, "A Proclamation Drawn for His Majesty's First Coming In, Prepared but Not Used," in $L L, 3: 69$. See further Commentarius Solutus, in SEH, 3:525; "Cyvilyzing Ireland, furder coloniz. y $\mathrm{e}^{\mathrm{e}}$ wild of Scotl. Annexing $\mathrm{y}^{\mathrm{e}}$ Lowe Countries," in SEH, 7:42.

${ }^{91} L L, 4: 113-15$.

${ }^{92}$ Ibid., 114.

${ }^{93}$ Compare $S E H, 7: 661$.

${ }^{94} L L, 4: 125$. See also Oxford English Dictionary, s.v. "hind."

${ }^{95}$ Bacon, "Of Plantations," in OFB, 15:106, lines 23-26.

${ }^{96}$ Bacon, Certain Considerations touching the Plantation in Ireland, in LL, 4:120.

${ }^{97}$ Ibid., 117. 
the legal notion of res nullius - no man's lands and empty spaces, but, importantly, for Bacon, Ulster is to be considered emptier than America. ${ }^{98}$ Only in "Of Plantations" in the 1625 edition of Bacon's Essayes, which is concerned above all with the Virginia Colony, does Bacon write against the extirpation of the native population. ${ }^{99}$ Bacon's Certain Considerations touching the Plantation in Ireland, addressed to Sir Robert Cecil, has no corresponding caveat against extirpating and removing the Irish from Ireland or from their homes and property there. ${ }^{100}$ Indeed, Bacon's depiction of the Irish there is in certain respects much harsher than his portrayal of Native Americans. Comparing the "Harp of Ireland" to the Harp of Orpheus in a passage of the Considerations which will recur in Bacon's 1609 De Sapientia Veterum, ${ }^{101}$ Bacon notes that the Orpheus fable "was anciently interpreted of the reducing and plantation of kingdoms; when people of barbarous manners are brought to give over and discontinue their customs of revenge and blood and of dissolute life and of theft and rapine, and to give ear to the wisdom of laws and governments." Of America, Bacon warns against extirpating native populations; of Ireland, he speaks of "reducing" the native populations of "people of barbarous manners."102

European engagement with Native Americans, in Bacon's understanding, is a matter of the ius gentium, the law of nations or the law of peoples, and requires treating Native Americans with the dignity and honor appropriate to a people that is a subject with respect to the law of nations. By contrast, in Bacon's view, English policy in Ireland is not a matter of the ius gentium, but rather a matter of internal administration and the suppression of rebellion, "a recovery of subjects"103 and a restitution of order in a territory which Bacon understood to be the property of the holder of the English

\footnotetext{
${ }^{98}$ See further Andrew Fitzmaurice, Sovereignty, Property and Empire, 1500-2000 (Cambridge: Cambridge University Press, 2014), 256-70; Ken MacMillan, Sovereignty and Possession, 9-12, 61-65.

${ }^{99}$ Bacon, “Of Plantations," in OFB, 15:106, lines 7-9: “I like a Plantation in a Pure Soile; that is, where People are not Displanted, to the end, to Plant in Others. For else, it is rather an Extirpation, then a Plantation." On the views of Bacon's predecessors writing on the juridical status of Native Americans, see Daragh Grant, "Francisco de Vitoria and Alberico Gentili on the Juridical Status of Native American Polities," Renaissance Quarterly 72, no. 3 (Fall 2019): 910-52. On early colonial treaties with Native American polities, see Daragh Grant, "The Treaty of Hartford (1638): Reconsidering Jurisdiction in Southern New England," William and Mary Quarterly 72, no. 3 (July 2015): 461-98.

${ }^{100}$ LL, 4:116-26. Cf. Irving, Natural Science, 9. However, see OFB, 8:205; SEH, 7:34.

${ }^{101}$ This textual repetition is noted in T. van Malssen, The Political Philosophy of Francis Bacon: On the Unity of Knowledge (Albany: State University of New York Press, 2015), 269 n102.

${ }^{102} L L, 4: 117-18$. See also Bacon, "A Proclamation," in LL 3:69; Commentarius Solutus, in $S E H, 3: 525 ; S E H, 7: 42$.

${ }^{103}$ LL, 2:130.
} 
crown. While Bacon mentions the ius gentium in his Considerations touching the Queen's Service in Ireland, he does so only to say that "proscriptions" or trialless executions of "two or three of the principal rebels" would be "no doubt jure gentium lawful," ${ }^{104}$ he raises this point only to recommend against the course of action which the ius gentium would sanction and proceeds swiftly to recommending the administration of Ireland under martial law, without regard to the law of nations. ${ }^{105}$

These two notions, namely, that both Virginia and Ireland are "Pure Soile" ripe for colonial planting and that Native Americans in the proximity of the Virginia Colony are to be respected when they do not make war upon the English settlers, might be thought to stand in some tension to one another. One might suggest that Bacon thought it fit for colonies to be established in those places where Native Americans did not have direct dwellings, "For else, it is rather an Extirpation, then a Plantation." ${ }^{106}$ In the case of America, Bacon would seem to foreground a title of occupation to the Virginia Colony, the notion that, as one scholar puts it, "something which belongs to nobody becomes the property of the first person to take it." 107 In the case of Ireland, as he states explicitly in his argument in Calvin's Case, ${ }^{108}$ Bacon foregrounds the title of conquest, thus shifting the legal title foregrounded as may be most appropriate to the situation and rhetorical context. But in both cases, imitating the policy he ascribes to his Henry VII in The History of the Raigne, Bacon advises his addressees to govern like conquerors, instituting martial law and ruling monarchically in their colonies newly established.

In his Declaration touching the Treasons of the Late Earl of Essex and His Complices, Bacon refers repeatedly to participants in Tyrone's Rebellion as "the rebels in Ireland"109 or simply "the rebels."110 A 1620/1 speech in Parliament would again class both the Desmond Rebellion and the Nine Years' War as "rebellions in Ireland." ${ }^{111}$ In keeping with this perspective on Ireland as a matter of internal administration, in his posthumously published eulogy for Queen Elizabeth's reign, In Felicem Memoriam Elizabethæ Anglix Reginx, Bacon classed Irish uprisings in the late Tudor period as the defection or rebellion in Ireland (de defectione in Hibernia) and those partaking in them as rebels (rebelles in Hibernia). ${ }^{112}$ The holder of the English crown in English law, in Bacon's assessment and that of his contemporaries, held the crown of Ireland as well, and Bacon thus regarded the same stratagems and

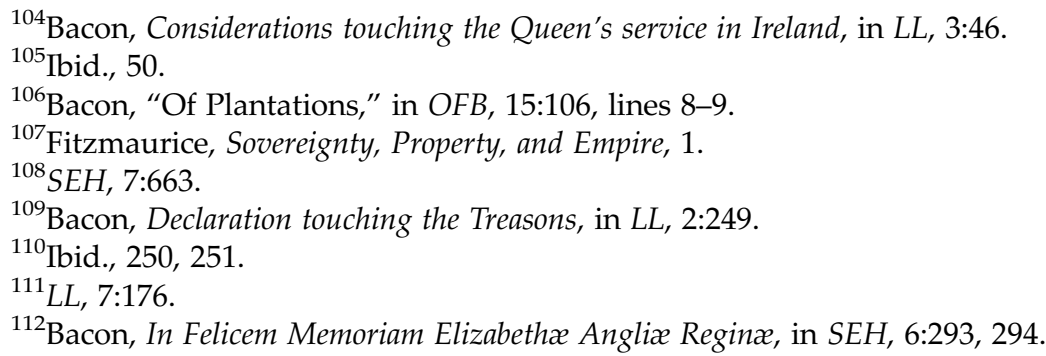


procedures, including martial law, to be as applicable to a rising in Ulster as to a rising in Lincolnshire. That Tyrone was considered to be a rebel allowed for the Crown to expropriate his lands upon his defeat, creating the precondition for the planting of County Tyrone. Bacon is thus in deadly earnest when he writes in his Certain Considerations that the plantation of Ulster and that of Virginia are sharply to be distinguished. Writing in his Considerations in passing of the "plantation for Virginia," Bacon is keen to emphasize that he regards this as "an enterprise in my opinion differing as much from this, as Amadis de Gaul differs from Cæsar's Commentaries." 113

\section{Toleration as a Stratagem of Empire}

In The Ideological Origins of the British Empire, David Armitage depicted the British Empire as constitutively Protestant such that "the frontiers of that extensive monarchy were guarded by a common religion and by the Royal Navy."114 While Bacon's view of a colonial empire was one in which the Kingdom of Britain held "the commandment of the sea," 115 the policing of colonial and imperial borders by "a common religion" is less clear in his thought. Indeed, in "Of Plantations" there is no mention of religion at all, rather plantations and colonies are associated with pre-Christian antiquity "amongst Ancient, Primitive, and Heroicall Workes,"116 and yet are nonetheless to be pursued for their stability, longevity, and profit. While Bacon does make reference to "God" and "his Service," ommend the building of churches in Virginia nor further that a plantation must have a fixed number of clergymen or, indeed, any at all. ${ }^{118}$ When enumerating the kinds of person with whom to plant a colony, clergy are conspicuously absent from an otherwise quite extensive list. ${ }^{119}$ Above all, Bacon makes no mention of proselytizing to or in any way attempting to convert native peoples to Christianity, but rather seems to caution against such engagement. ${ }^{120}$ The most that the colonial power may responsibly do is sponsor travel by native peoples to the cities of the colonizing power "that they may see a better Condition then their owne, and commend it when they returne."121

In his Considerations touching the Queen's service in Ireland addressed to Secretary Robert Cecil, following the defeat of Tyrone's forces in Ireland on

${ }^{113} L L, 4: 123$. Compare $L L, 2: 127$.

${ }^{114}$ David Armitage, The Ideological Origins of the British Empire (Cambridge:

Cambridge University Press, 2000), 1; see further 8, 62, 65, 69-70.

${ }^{115}$ Bacon, "Of the True Greatness of the Kingdom of Britain," in SEH, 7:49.

${ }^{116}$ Bacon, "Of Plantations," in OFB, 15:106, line 3.

${ }^{117}$ Ibid., 107, lines 69-70.

${ }^{118}$ Ibid., 106-8.

${ }^{119}$ Ibid., 106, lines 23-26.

${ }^{120}$ Ibid., 108, lines 91-98.

${ }^{121}$ Ibid., lines 97-98. See also MacMillan, Sovereignty and Possession, 9. 
Christmas Eve of 1601, Bacon argues strongly against the forcing of Catholic consciences to Protestantism in Ireland, proposing instead toleration for Catholicism there, even to the point of allowing English Catholics to leave England for Ireland. The toleration that Bacon favors is both explicitly unlimited in its temporal scope and to be modeled on the contemporaneous policies of Henri IV in France, writing that "a toleration of religion (for a time not definite) except it be in some principal towns and precincts, after the manner of some French edicts, seemeth to me to be a matter warrantable by religion, and in policy of absolute necessity." ${ }^{122}$ Among the "French edicts" which Bacon seems to endorse as appropriate models of toleration may be the famous Edict of Nantes of April 1598, which granted toleration to Huguenot Protestants in France. ${ }^{123}$ While Bacon does balance his policy of toleration with the promotion of Protestantism in Ireland, the modes he counsels are noncoercive such as "the sending over of some good preachers" as well as the sponsorship of Protestant educational institutions through "the recontinuing and replenishing the college begun at Dublin"124 alongside the sponsorship of Gallic vernacular Bibles paid for by the English Crown. He advocates "the sending over of some good preachers" as much as a politic compromise to make toleration politically palatable in England "for the avoiding of scandal and insatisfaction here by the show of a toleration of religion in some parts there."125

This recommendation for toleration connects Bacon's reflections in "Of Empire" to his specific proposals and white papers on plantations and colonies. In "Of Empire," Bacon cautiously counseled monarchs or would-be monarchs with respect to "their Commons," writing that "There is little danger from them, except it be, where they have Great and Potent Heads; Or where you meddle, with the Point of Religion." ${ }^{126}$ To force conversion in Ireland, to imitate the Spanish Inquisition, or to plant Protestantism by means other than persuasive, would seem, at least initially, to amount to meddling in the point of religion, one of the few, though potent, factors which may make "the Commons" a danger to a monarch and stir them to rebellion and revolt. In his Considerations touching the Queen's service in Ireland, Bacon would make a similar point, claiming that "one of the principal pretences whereby the heads of the rebellion have prevailed both with the people and with the foreigner, hath been the defence of the Catholic

\footnotetext{
${ }^{122}$ Bacon, Considerations touching the Queen's service in Ireland, in LL, 3:49.

${ }^{123}$ Mark Greengrass, Christendom Destroyed: Europe 1517-1648 (London: Penguin Books, 2015), 564, 578.

${ }^{124}$ On the Bacon family's support for Trinity College, Dublin, see Lady Anne Bacon's letter to William Cecil, Lord Burghley, dated May 22, 1595, in The Letters of Lady Anne Bacon, ed. Gemma Allen (Cambridge: Cambridge University Press for the Royal Historical Society, 2014), 218.

${ }^{125}$ Bacon, Considerations touching the Queen's service in Ireland, in $L L, 3: 49$.

${ }^{126}$ Bacon, "Of Empire," in OFB, 15:62, lines 148-50.
} 
religion." ${ }^{127}$ Bacon counsels the removal of the pretense for rebellion through the toleration of Catholicism in Ireland. As one especially concerned to restore Ireland to its obedience to the holder of the English crown, ${ }^{128}$ Bacon's advocacy of toleration of Catholicism there may be seen to be consistent with his broader counsels on how best to keep the common people and those who might stir them up in obedience to the holders of imperial and monarchic power.

\section{Conclusion}

Bacon's thought on colonial and imperial warfare hinges importantly on the title of conquest, which he took to be natural and to ground future legality in places acquired by conquest. Conquest, however, as we have seen, carried ideological baggage in late Tudor and early Stuart political discourse. Bacon distinguished the public act of claiming a title to conquest from the politic posture of ruling as a conqueror (instituting martial law and ruling monarchically) under various titles, and he exhorted his addressees in colonial and imperial matters to do the latter. In this regard, Bacon's concern with imperial and colonial warfare is intimately linked to his concern with warfare closer to home, with the maintenance of internal order and the prevention of civil war.

Against interpretations that colonization and empire did not play any or any significant role in Bacon's thought, the present article has moved from presenting Bacon's view that conquest confers legal title to his advocacy for wars for colonial plantations and empire in his essays "Of Plantations" and "Of Empire." From there, the article laid out Bacon's views on the place of colonial and imperial warfare within Bacon's writings on greatness and his view that internal rebels (under which heading he viewed Irish opponents of colonization) forfeit their juridical status under the laws of treason. The article then offered an interpretation of Bacon's colonial proposals for Ireland to argue for the capacious scope of colonial and imperial warfare within his thought, looking particularly at Bacon's view of religious toleration as a stratagem of imperial rule.

In part, this article has confirmed an older conception of Bacon's political thought: "Bacon prefers a monarchical government of cautious imperialistic disposition to stimulate science, civic peace, commerce and religious toleration." ${ }^{129}$ But only in part: there was very little caution in Bacon's imperialism, and his enthusiasm for colonial and imperial expansion meant expanding not cautiously, but at a rate aimed specifically at overtaking (or at the very least

\footnotetext{
${ }^{127}$ Bacon, Considerations touching the Queen's service in Ireland, in LL, 3:49.

${ }^{128}$ Bacon, Certain Considerations touching the Plantation in Ireland, in LL, 4:116.

${ }^{129}$ R. A. Melvin, review of Peace among the Willows by H. B. White, APSR 64, no. 1 (March 1970): 200.
} 
matching) the expansion of the Spanish Empire - to expand at a slower rate would risk upending the balance of power in Europe permanently in Spain's favor to the detriment of both England and France. Modifying this view further, as we have seen, Bacon's preference for religious toleration was not only an end or aim of his policy of colonial plantations; it was a means for their stable government and retention as well.

Most clearly in "Of the True Greatness of the Kingdom of Britain," Bacon argues that in the Britain of his time, the conditions obtain either for civil war or for external imperial expansion: a warlike populace, an excessively large nobility, and a great disparity of wealth between the two, such that, as Bacon quotes Lucan, war is profitable to many: these many can either be sent to colonize other places, such as Ireland, America, or perhaps the Spanish Netherlands ${ }^{130}$ or Spain itself for that matter, or they can stay put, in which case civil war is possible, perhaps even likely. Bacon thinks that imperial expansion is preferable to civil war, and that Britain is faced with something of a binary choice. This assessment shapes his thought on empire, colonies, and an external policy of expansion as a whole. However, faced with the choice between civil war and empire in the seventeenth century, Britain, tragically, chose both.

${ }^{130}$ See Bacon's diary from the final days of July 1608, the Commentarius Solutus, in $L L$, 4:50-94, in which he contemplates "Annexing $y$ e Lowe Countries," a position which he also articulates in his Certain Observations upon a Libel from almost two decades prior. On Bacon's thought on this matter, see Serjeantson, "Limits of Atlanticism." 